\title{
Left atrial thrombus in a patient with left atrial appendage ligation
}

\author{
Andrew H Lin, ${ }^{1}$ Luke S Oakley, ${ }^{2}$ David J Krause, ${ }^{1}$ Gregory M Francisco ${ }^{1}$
}

'Department of Cardiology, Naval Medical Center San Diego, San Diego, California, USA

${ }^{2}$ Department of Internal Medicine, Naval Medical

Center San Diego, San Diego, California, USA

\section{Correspondence to}

Dr Andrew H Lin,

alin_1974@yahoo.com
To cite: Lin AH, Oakley LS, Krause DJ, et al. BMJ Case Reports Published online: [please include Day Month Year] doi:10.1136/bcr-2012 008342

\section{DESCRIPTION}

A 75-year-old woman who had a bioprosthetic mitral valve replacement and complete left atrial appendage (LAA) ligation a year ago was found to be in atrial flutter at routine clinical follow-up. She was started on warfarin and brought back for a transoesophageal echocardiogram (TOE)-guided cardioversion. On the TOE, a left atrial thrombus overlying the ligated LAA was discovered (figure 1). The patient was asymptomatic, and since she had a CHADS score of 2, we continued her on warfarin indefinitely. She was set-up for a repeat TOE and cardioversion 1 month later. During this TOE, she demonstrated resolution of the thrombus (figure 2) and subsequent successful cardioversion. A couple of months later, she had a successful atrial flutter ablation procedure performed.

The LAA is a common site for thrombus formation and thus the origin of many cardioembolic events. Ligation of the LAA during valvular surgery is often performed with the intent of minimising the risk of thrombus formation. However, patients remain at risk for thromboembolic events even after LAA ligation. ${ }^{1}$ Prior reports have documented thrombi formation after disruption of the suture line. ${ }^{2} 3$ Here, we extend these findings and demonstrate that left atrial thrombus formation is still possible despite a complete and intact left atrial appendage ligation.

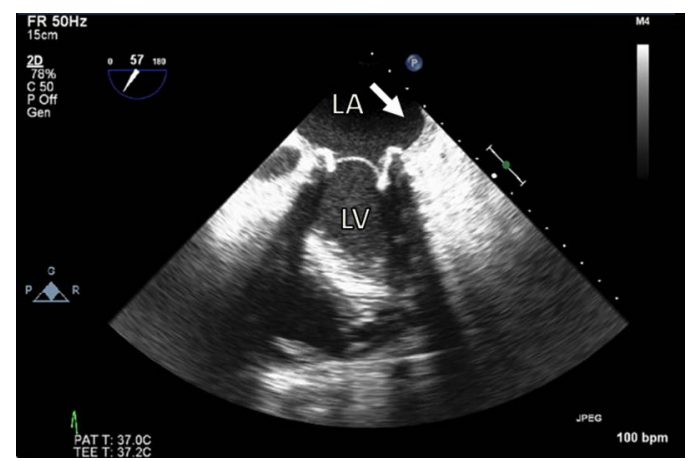

Figure 2 Trans-oesophageal echocardiogram. A mid-oesophageal two chamber view after 1 month of anticoagulation demonstrating resolution of the left atrial thrombus. Note the complete left atrial appendage ligation (arrow). LA, left atrium; LV, left ventricle.
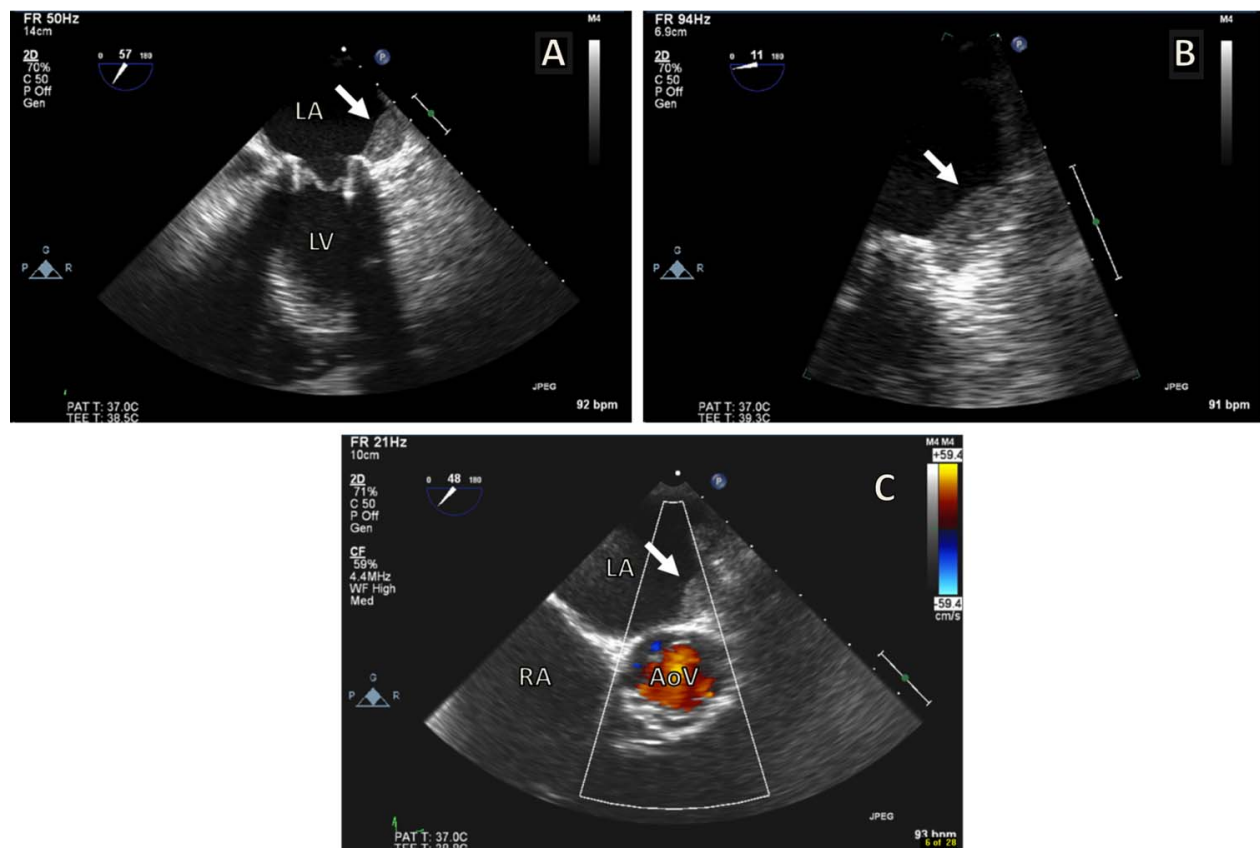

Figure 1 Transoesophageal echocardiogram. A mid-oesophageal two chamber image (A) and enlarged view (B) of the bioprosthetic mitral valve and a completely ligated left atrial appendage with an overlying atrial thrombus (arrow). (C) A mid-oesophageal short-axis view showing the thrombus in the left atrium. AoV, aortic valve; RA, right atrium; LA, left atrium; LV, left ventricle. 


\section{Learning points}

- Left atrial appendage ligation does not eliminate the risk of thromboembolic events.

- Transoesophageal echocardiograms are still required in patients with left atrial appendage ligations prior to cardioversion.

Competing interests None.
Patient consent Obtained.

Provenance and peer review Not commissioned; externally peer reviewed.

\section{REFERENCES}

1 Whitlock RP, Healey JS, Connolly SJ. Controversies in cardiovascular medicine. Circulation 2009;120:1927-32.

2 Katz ES, Tsiamtsiouris T, Applebaum RM, et al. Surgical left atrial appendage ligation is frequently incomplete: a transoesophageal echocardiographic study. J Am Coll Cardiology 2000;36:468-71.

3 Donnino R, Tunick PA, Kronzon I. Left atrial appendage thrombus outside of a 'successful' ligation. Euro J Echocardiogr 2008;9:397-8.

Copyright 2013 BMJ Publishing Group. All rights reserved. For permission to reuse any of this content visit http://group.bmi.com/group/rights-licensing/permissions.

BMJ Case Report Fellows may re-use this article for personal use and teaching without any further permission.

Become a Fellow of BMJ Case Reports today and you can:

- Submit as many cases as you like

- Enjoy fast sympathetic peer review and rapid publication of accepted articles

- Access all the published articles

- Re-use any of the published material for personal use and teaching without further permission

For information on Institutional Fellowships contact consortiasales@bmjgroup.com

Visit casereports.bmj.com for more articles like this and to become a Fellow 